\title{
Investigation of Methicillin Resistance and Panton-Valentine Leukocidin in Staphylococci Isolated from Bovine Mastitis*
}

\author{
Cansu Gezgen ${ }^{1} \&$ Esra Seker ${ }^{2}$
}

\begin{abstract}
Background: Mastitis, which is inflammation of the mammary gland, is among the most important diseases in dairy herds resulting in reductions of milk yield and milk quality. Although several groups of microorganisms have been reported as etiological agents of mastitis, Staphylococci are the most frequently isolated bacteria from bovine mastitic milk samples. The aim of this study was to isolate the Staphylococcus species from bovine mastitis, investigate the mecA ve $p v l$ genes in isolated species by PCR and determine the antibiotic resistance of methicillin resistant strains to some antibiotics commonly used in veterinary field.

Materials, Methods \& Results: In the present study, 972 half-udder milk samples ( $\mathrm{n}=757$ CMT positive, $\mathrm{n}=215$ CMT negative) were used from 251 lactating cows from 34 different enterprises located center town and villages of Ödemiş, İzmir. Ten microliters of each milk sample was inoculated onto Columbia blood agar, containing $7 \%$ of sheep blood and incubated under aerobic conditions for $24-48 \mathrm{~h}$ at $37^{\circ} \mathrm{C}$. The certain identification of Staphylococcus isolates was achieved using Crystal ${ }^{\mathrm{TM}}$ Identification Systems Gram-Positive ID kit. Bacterial DNAs were extracted from all strains using boiling method and strains were screened for the presence of $16 \mathrm{~S}$ rDNA, mecA and $p v l$ genes by PCR. The antimicrobial resistance of MRS species was determined by using disc diffusion method. A total of $182(18.72 \%)$ Staphylococcus strains were isolated from 972 half-udder milk samples. Of 182 Staphylococcus strains, 137 (75.27\%) and $45(24.73 \%)$ were detected as CPS and CNS, respectively. Among the 11 different Staphylococcus species, S. intermedius (42.30\%) was the most common species isolated, followed by S. aureus (32.97\%) and S. saprophyticus (10.99\%). The mecA positivity was found in only $4(2.2 \%)$ S. intermedius strains, while $p v l$ toxin gene was determined in none of the strains. Four MR S. intermedius strains were resistant to oxacillin and cefoxitin. The resistance was also found to erythromycin (50\%), rifampicin (25\%), gentamicin (25\%), tetracycline (25\%) and trimethoprim/sulfamethoxazole $(25 \%)$ in the isolates.

Discussion: In this study, S. intermedius had the highest isolation rate and this finding was considered remarkable. Generally, in mastitis diagnostics all CPS isolates are classified as S. aureus. In our study, the certain identification of all CPS may explain the high isolation rate of $S$. intermedius. The sampling method may also be the reason of higher isolation rate for $S$. intermedius in accordance with the most common ones causing mastitis. All of mecA positive strains were S. intermedius and this was the another remarkable finding of our study. Because similar result was seen in only one study from Korea, while the investigation finding related to MR S. intermedius was not determined in Turkey. However, the $m e c A$ positivity found in our study was lower than the other author's isolation rate. The difference between the sample size, geographical variations and diversity in strains may be the causes of this discrepancy. It was investigated $p v l$ toxin gene in 182 Staphylococcus strains by PCR and found this gene in none of strains. According to this finding, it was considered that $p v l$ gene may have not an efficient role in the pathogenesis of mastitis in terms of sampled animals and sampling area. Antibiotic resistance of 4 MR S. intermedius strains against various antibiotics commonly used in Turkey was investigated. Of methicillin resistant strains, 2, 1 and 1 were resistant to 3, 6 and 5 antibiotics, respectively. It was considered that geographical differences, number of tested isolates and diversity in MR strains may be effective on the antibiotic resistance levels. This is the first study showing the presence of mecA gene in S. intermedius strains isolated from bovine mastitic milk samples in Turkey.
\end{abstract}

Keywords: antimicrobial resistance, mastitis, methicillin resistance, Panton-Valentine leukocidin, Staphylococcus spp. 
C. Gezgen \& E. Seker. 2016. Investigation of Methicillin Resistance and Panton-Valentine Leukocidin in Staphylococci

\section{INTRODUCTION}

Mastitis, which is defined as an inflammatory reaction of mammary gland, continues to be prominent problem affecting the animal and public health in dairy industry $[2,10,12]$. Among several groups of microorganisms playing role in the etiology of mastitis, Staphylococci are the most frequently isolated bacteria from bovine mastitic milk samples [9,21,24,32]. Methicillin resistant Staphylococci (MRS) have been considered as an emerging problem in veterinary medicine in recent years [22,29,33]. Methicillin resistance is mediated by the mecA gene located on the chromosome of MRS. MRS are often resistant to antimicrobials both all $\beta$-lactams and other than $\beta$-lactams are widely used in both human and veterinary medicine $[11,25]$. PantonValentine leukocidin (PVL) is a cytotoxin believed by many researchers to be responsible for the severe symptoms of Staphylococcus aureus infections [17,18]. However, the pathogenic role of PVL in the pathogenesis of mastitis is still controversial $[15,34,38]$.

In Turkey, the studies investigating the presence of mecA and $p v l$ toxin genes in Staphylococci isolated from mastitic milk samples are limited $[7,34]$. Therefore, this study was aimed to isolate the Staphylococcus species from bovine mastitis, investigate the mecA ve $p v l$ genes in isolated species by Polymerase Chain Reaction (PCR) and determine the antibiotic resistance of methicillin resistant strains to some antibiotics commonly used in veterinary field. To our knowledge, this is the first study investigating the presence of mecA and $p v l$ genes in the Staphylococci isolated from quarter milk samples in İzmir province of Turkey.

\section{MATERIALS AND METHODS}

\section{Milk samples and bacteriological identification}

A total of 972 half-udder milk samples were collected from 251 lactating cows on 34 different private enterprises in the center town and villages of Ödemiş, located in the İzmir province of Turkey. No antibiotics had been applied to the animals in the previous three months. Firstly, California mastitis test (CMT) was applied for each mammary quarter according to the method described by Schalm et al. [28] and scores were evaluated as $+1,+2,+3$ and negative. Before sampling for bacteriologic examination, the teat ends were cleaned by $70 \%$ alcohol and dried. The first streams of foremilk were discharged, and then $10 \mathrm{~mL}$ of milk was collected aseptically from each udder half into sterile vials. Samples were immediately transported to the laboratory in a cool box on ice. Ten $\mu \mathrm{L}$ of each milk sample was inoculated onto Columbia blood agar ${ }^{1}$, containing $7 \%$ of sheep blood and incubated under aerobic conditions for 24-48 h at $37^{\circ} \mathrm{C}$. The infection status of milk samples were determined according to the procedures recommended by the National Mastitis Council [23]. Intramammary infection was defined when $\geq 500 \mathrm{cfu} / \mathrm{mL}$ colonies were found. Each different colony was examined macroscopically (colony morphology, haemolysis, pigment production) and microscopically (Gram staining). Then oxidase, catalase, slide and tube coagulase and anaerobic fermentations of glucose and mannitol tests were performed to suspected colonies [13]. The certain identification of Staphylococcus isolates was achieved using Crystal ${ }^{\mathrm{TM}}$ Identification Systems GramPositive ID kit ${ }^{2}$. In all tests, methicillin resistant $S$. aureus (MRSA) ATCC ${ }^{\circledR} 33591$ and methicillin sensitive S. aureus (MSSA) ATCC ${ }^{\circledR} 25923$ were used as control strains ${ }^{1}$. All isolates identified were stored at $-20^{\circ} \mathrm{C}$ in brain heart infusion broth containing $15 \%$ glycerol until further analysis.

Detection of $16 \mathrm{~S}$ rDNA, mecA and pvl genes in Staphylococcus spp. by PCR

DNA was extracted from the positive controls ${ }^{1}$ (MRSA ATCC ${ }^{\circledR} 33591$ and PVL S. aureus ATCC $^{\circledR}$ 49775), negative control ${ }^{1}$ (MSSA ATCC ${ }^{\circledR} 25923$ ) and all test strains using boiling method. For this purpose, all strains were inoculated onto Trypticase Soy Agar ${ }^{1}$. After the incubation, fresh colonies were suspended in $500 \mu \mathrm{L}$ of DEPC-treated water (DNase-RNase free). The suspension was held in a $100^{\circ} \mathrm{C}$ of water bath for $10 \mathrm{~min}$. After centrifugation at 9,167 $g$ for $5 \mathrm{~min}$, the supernatant containing bacterial DNA was used as a template for subsequent PCR mixture [39].

The oligonucleotide primers described by Strommenger et al. [30], Choi et al. [4] and Lina et al. [17] were used for the detection of $16 \mathrm{~S}$ rDNA (Staphylococcus spp. specific), mecA (methicillin resistance specific) and $p v l$ (Panton-Valentine toxin specific) genes, respectively. For the detection of a 420 bp 16S rDNA gene forward 5'-CAGCTCGTGTCGTGAGATGT-3' and reverse 5'-AATCATTTGTCCCACCTTCG-3' primers, a 314 bp mecA gene forward 5'-CCTAGTAAAGCTCCGGAA-3' and 
reverse 5'-CTAGTCCATTCGGTCCA-3' primers were used. Amplification of a $433 \mathrm{bp} p v l$ gene was performed using the forward 5'-ATCATTAGGTAAAATGTCTGGACATGATCCA-3' and reverse 5'-GCATCAASTGTATTGGATAGCAAAAGC-3' primers. Five $\mu \mathrm{L}$ of the extracted DNA were used as a template in a 25 $\mu \mathrm{L}$ PCR mixture containing 10X PCR buffer, $25 \mathrm{mM}$ $\mathrm{MgCl} 2,10 \mathrm{mM}$ dNTP mix, $20 \mu \mathrm{M}$ each primers, $1 \mathrm{U}$ of Taq DNA polymerase and deionized water. The PCR amplification conditions of $16 \mathrm{~S}$ rDNA and mecA genes consisted an initial denaturation step at $95^{\circ} \mathrm{C}$ for 5 min, and 30 cycles of $95^{\circ} \mathrm{C}$ for $2 \mathrm{~min}, 54^{\circ} \mathrm{C}$ for $1 \mathrm{~min}$, $72^{\circ} \mathrm{C}$ for $1 \mathrm{~min}$ and a final step $72^{\circ} \mathrm{C}$ for $7 \mathrm{~min}$. The amplification cycles of $p v l$ gene were programmed as $5 \mathrm{~min}$ at $95^{\circ} \mathrm{C}$ for initial denaturation; 30 cycles, $30 \mathrm{~s}$ at $94^{\circ} \mathrm{C}, 30 \mathrm{~s}$ at $62^{\circ} \mathrm{C}, 1 \mathrm{~min}$ at $72^{\circ} \mathrm{C}$; and $5 \mathrm{~min}$ final extension step at $72^{\circ} \mathrm{C}$. All products were analyzed by $1.5 \%$ agarose gel electrophoresis and visualized using ethidium bromide under U.V. light. Molecular size markers ${ }^{3}$ (100-bp DNA ladder) were included in each agarose gel.

\section{Antimicrobial Susceptibility Test}

The antimicrobial resistance of MRS species was determined by using Kirby-Bauer disc diffusion method test on Mueller Hinton agar ${ }^{1}$, according to the guidelines of the Clinical and Laboratory Standards Institute [6]. For this purpose, amoxicillin+clavulanic acid $(30 \mu \mathrm{g})$, enrofloxacin $(5 \mu \mathrm{g})$, cefoxitin $(30 \mu \mathrm{g})$, oxacillin $(1 \mu \mathrm{g})$, cephalothin $(30 \mu \mathrm{g})$, rifampicin $(5 \mu \mathrm{g})$, gentamicin $(10 \mu \mathrm{g})$, erythromycin $(15 \mu \mathrm{g})$, tetracycline
$(30 \mu \mathrm{g})$ and trimethoprim/sulfamethoxazole $(25 \mu \mathrm{g})$ antibiotic discs ${ }^{1}$ were used. While the plates including oxacillin and cefoxitin discs were incubated at $35^{\circ} \mathrm{C}$ for $24 \mathrm{~h}$, the other plates were incubated at $37^{\circ} \mathrm{C}$ for $18 \mathrm{~h}$ (CLSI, 2013). MRSA ATCC ${ }^{\circledR} 33591$ and MSSA ATCC $25923^{\circledR}$ were used as positive and negative quality control strains 1 , respectively.

\section{RESULTS}

\section{Isolation and identification findings}

A total of 182 (18.72\%) Staphylococcus spp. were identified from 972 half-udder milk samples (757 CMT positive, 215 CMT negative) belong to 251 lactating cows by using Crystal ${ }^{\mathrm{TM}}$ Identification Systems Gram-Positive ID kit. It was determined that $120(47.8 \%)$ of 251 cows were infected with the least one Staphyloccus species. Of 182 Staphylococcus strains, $137(75.27 \%)$ were found as coagulase-positive Staphylococci (CPS) and $45(24.73 \%)$ as coagulasenegative Staphylococci (CNS). A total of 11 different species were identified in this study. The most frequently isolated species were Staphylococcus intermedius (42.30\%), followed by S. aureus (32.97\%) and Staphylococcus saprophyticus (10.99\%). The identified species and their isolation rates were shown in Table 1. Also, 122 (16.11\%) and 60 (27.90\%) Staphylococcus species were isolated from $757 \mathrm{CMT}$ positive and 215 CMT negative milk samples, respectively. The distribution of species according to CMT scores was shown in Table 2.

Table 1. Identified Staphylococcus species from dairy cow quarter milk samples and their isolation rates.

\begin{tabular}{ccc}
\hline Species & $\mathrm{n}$ & $\%$ \\
\hline S. aureus & 60 & 32,97 \\
S. intermedius & 77 & 42,30 \\
S. saprophyticus & 20 & 10,99 \\
S. haemolyticus & 11 & 6,04 \\
S. simulans & 5 & 2,75 \\
S. capitis & 3 & 1,65 \\
S. epidermidis & 2 & 1,10 \\
S. kloosii & 1 & 0,55 \\
S. sciuri & 1 & 0,55 \\
S. schleiferi subsp. schleiferi & 1 & 0,55 \\
S. auricularis & 1 & 0,55 \\
\hline Total & 182 & 100 \\
\hline
\end{tabular}


Table 2. Distribution of Staphylococcus species isolated from dairy cow quarter milk samples according to CMT scores.

\begin{tabular}{ccccc}
\hline \multirow{2}{*}{ Species $(\mathrm{n}=182)$} & $+1(\mathrm{n})$ & $+2(\mathrm{n})$ & $+3(\mathrm{n})$ & Negative (n) \\
\cline { 2 - 5 } S. aureus & 15 & 27 & 9 & 9 \\
S. intermedius & 18 & 21 & 8 & 30 \\
S. saprophyticus & 1 & 6 & 1 & 12 \\
S. haemolyticus & 4 & 1 & 1 & 5 \\
S. simulans & 1 & 2 & 2 & - \\
S. capitis & 1 & - & - & 2 \\
S. epidermidis & - & 2 & - & - \\
S. kloosii & 1 & - & - & - \\
S. sciuri & 1 & - & - & 1 \\
S. scleiferi subsp. scleiferi & - & - & - & $60(32.97 \%)$ \\
S. auricularis & - & - & - & - \\
Total & $42(23.07 \%)$ & $59(32.42 \%)$ & $21(11.54 \%)$ &
\end{tabular}

\section{PCR findings}

$16 \mathrm{~S}$ rDNA specific bands were seen in all of 182 Staphylococcus isolates obtained from half-udder milk samples, 4(2.2\%) of these harboured the mecA gene. It was also detected all of $m e c A$ positive strains were $S$. intermedius. Thus, the mecA positivity was found to be $5.19 \%$ in 77 $S$. intermedius isolates. Two of methicillin resistant $S$. intermedius strains were obtained from the same enterprises. In our study, none of the isolates had $p v l$ toxin gene. Amplification of 16S rDNA (420 bp) and mecA (314 bp) genes in S. intermedius strains was shown in Figure 1.

\section{Antimicrobial susceptibility test}

According to Kirby-Bauer disc diffusion test results, all of methicillin resistant $S$. intermedius strains were resistant to oxacillin and cefoxitin, while they were sensitive to amoxicillin+clavulanic acid and cephalothin. The resistance to erythromycin (50\%), rifampicin $(25 \%)$, gentamicin $(25 \%)$, tetracycline (25\%) and trimethoprim/sulfamethoxazole (25\%) was also found in the mecA positive $S$. intermedius strains. Antibiotic resistance of MR $S$. intermedius strains was shown in Table 3.

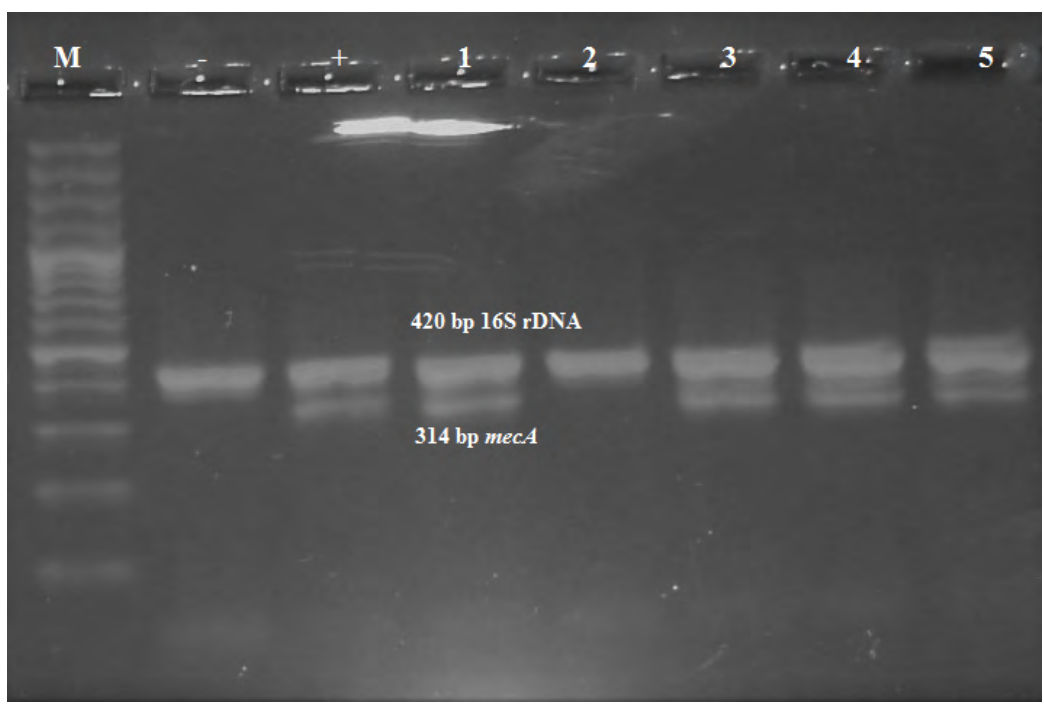

Figure 1. Detection of $16 \mathrm{~S}$ rDNA and mecA genes by mPCR. M: 100 bp DNA ladder; -: negative control (MSSA ATCC $囚 25923$ ); +: positive control (MRSA ATCC $(33591$ ); lane 1,3-5: mecA gene positive $S$. intermedius strains; lane 2: mecA gene negative Staphylococcus isolate. 
C. Gezgen \& E. Seker. 2016. Investigation of Methicillin Resistance and Panton-Valentine Leukocidin in Staphylococci

Table 3. Antibiotic resistance of 4 MR S. intermedius strains.

\begin{tabular}{cccccccc}
\hline & \multicolumn{6}{c}{ mecA positive S. intermedius $(\mathrm{n}=4)$} \\
\cline { 2 - 8 } Antibiotic & \multicolumn{3}{c}{$\mathrm{S}$} & \multicolumn{1}{c}{$\mathrm{I}$} & \multicolumn{3}{c}{$\mathrm{R}$} \\
\cline { 2 - 8 } & $\mathrm{n}$ & $\%$ & $\mathrm{n}$ & $\%$ & $\mathrm{n}$ & $\%$ \\
\hline Amoxicillin+clavulanic acid $(30 \mu \mathrm{g})$ & 4 & 100 & - & 0 & - & 0 \\
Enrofloxacin $(5 \mu \mathrm{g})$ & 3 & 75 & 1 & 25 & - & 0 \\
Cephalothin $(30 \mu \mathrm{g})$ & 4 & 100 & - & 0 & - & 0 \\
Rifampicin $(5 \mu \mathrm{g})$ & 3 & 75 & - & 0 & 1 & 25 \\
Gentamicin $(10 \mu \mathrm{g})$ & 3 & 75 & - & 0 & 1 & 25 \\
Erythromycin $(5 \mu \mathrm{g})$ & 1 & 25 & 1 & 25 & 2 & 50 \\
Tetracycline $(30 \mu \mathrm{g})$ & 3 & 75 & - & 0 & 1 & 25 \\
Trimethoprim/sulfamethoxazole $(25 \mu \mathrm{g})$ & 3 & 75 & - & 0 & 1 & 25 \\
Oxacillin $(1 \mu \mathrm{g})$ & - & 0 & - & 0 & 4 & 100 \\
Cefoxitin $(30 \mu \mathrm{g})$ & - & 0 & - & 0 & 4 & 100 \\
\hline
\end{tabular}

S: Sensitive; I: Intermediate; R: Resistant.

\section{DISCUSSION}

The present study investigated the presence of $m e c A$ and $p v l$ genes in Staphylococcus spp. isolated from bovine mastitic milk samples by PCR and the antibiotic resistance of methicillin resistant strains to antibiotics commonly used in veterinary field.

Staphylococci are the most common bacterial agents isolated from bovine with mastitis. However, the distribution of species obtained from the studies related to the etiology of Staphylococcal mastitis have shown the variation [14,24,36]. Vishnupriya et al. [36] reported that 22 and 74 of 96 Staphylococcus spp. isolated from $158 \mathrm{CMT}$ positive milk samples were CPS and CNS, respectively. In the same study, the most frequently isolated species were found to be $S$. aureus $(\mathrm{n}=20)$ and Staphylococcus epidermidis $(\mathrm{n}=17)$. In a study, it was reported that $113(71.5 \%)$ Staphylococcus spp. were isolated from $158 \mathrm{CMT}$ positive milk samples, of these 5 and 108 were found to be S. aureus and CNS, respectively. It was also emphasized Staphylococcus haemolyticus and Staphylococcus chromogenes were the most frequently isolated species among the CNS [14]. Pehlivanoğlu \& Yardımcı [24] from Turkey reported the highest isolation rate belonged to $S$. aureus $(\mathrm{n}=65)$ and $S$. intermedius $(\mathrm{n}=17)$ among the 100 Staphylococcus strains isolated from CMT positive half-udder milk samples. In our study, of 182 Staphylococcus isolates obtained from 972 mammary quarter milk samples, 137 (75.27\%) were determined to be CPS and 45 (24.73\%) to be CNS. Among the 11 different Staphylococcus species, $S$. intermedius $(\mathrm{n}=$ 77 ; $42.30 \%$ ) was the most common species isolated, followed by $S$. aureus $(\mathrm{n}=60 ; 32.97 \%)$ and S. saprophyticus $(\mathrm{n}=20 ; 10.99 \%)$ (Table 1$)$. Compared with the other investigation results [14,24,36], while the similarity in terms of isolated species was found, the differences were detected in the isolation rates of species. In the present study, the high isolation rate of $S$. intermedius was remarkable for us. Taponen [31] has emphasized that in mastitis diagnostics all CPS isolates are usually classified as $S$. aureus and all other isolates as CNS. In our study, the identification of all CPS was achieved by using identification kit. This certain identification may explain the high isolation rate of $S$. intermedius. Unlike other studies, we also made the bacterial isolation from both CMT positive and CMT negative milk samples. It was considered this sampling method may be the reason of higher isolation rate for $S$. intermedius in accordance with the most common ones causing mastitis. In the present study, S. saprophyticus was the predominant CNS species and this was another remarkable finding of our study. Taponen [31] has reported that $S$. saprophyticus may be found in the cows' environment. However, some researchers emphasized that the increase was determined in the isolation rate of this agent from animals with mastitis $[3,37]$. 
The California mastitis test has been accepted as a quick and simple screening test to predict somatic cell count from individual quarters or composite milk. However, microbiological growth has been shown in CMT negative mammary quarters as well as CMT positive ones [2]. Bhutto et al. [2] detected the bacteriological growth in the $57.6 \%$ of CMT negative half-udder milk samples, while bacteriological isolation from CMT negative milk samples was found to be $30.1 \%$ in another study [1]. We collected 972 half-udder milk samples, of which was 757 CMT positive and 215 CMT negative. The isolation rate of Staphylococcal agents from CMT negative half-udder milk samples was found to be $32.97 \%$, while this rate was $16.11 \%$ in CMT positive ones (Table 2). According to some authors, the sensitivity and specificity of CMT are unsteady and also sensitivity of CMT may be low for different pathogens [26,27].

Methicillin resistance is mediated by the mecA gene located on the chromosome of MRS [25]. Various researchers have reported the different $m e c A$ prevalence in Staphylococci, especially $S$. aureus, isolated from bovine mastitic milk samples [5,7,8,19,22,24]. In a study from Germany, 15 (12.39\%) of $121 \mathrm{CNS}$ isolates were determined to be $m e c A$ positive [8]. Moon et al. [22] found the mecA positivity in 13 and 12 of 835 $S$. aureus and $763 \mathrm{CNS}$ strains, respectively, while the mecA positivity was found to be $9.2 \%(\mathrm{n}=15)$ in 163 $S$. aureus strains in another study [19]. Similarly, the investigation results related to the presence of $m e c A$ in Staphylococci are variable in Turkey. In a study, methicillin resistance was found in 20 of 100 Staphylococcus strains [24], while Erdem \& Türkyılmaz [7] determined mecA positivity in only two of $S$. aureus strains isolated from 145 mastitic milk samples. In another investigation, only $4(6.7 \%)$ of $59 \mathrm{~S}$. aureus isolates were found to be MRSA [5]. In our study, 16S rDNA specific bands were detected in all of 182 Staphylococcus isolates obtained from half-udder milk samples, $4(2.2 \%)$ of these harboured the mecA gene. All of mecA positive strains were $S$. intermedius and this result was remarkable for us. When the comprehensive literature investigation was made, the report on MR S. intermedius was seen in only one research from Korea. In this study, Moon et al. [22] reported that only one of $20 \mathrm{MRS}$ strains was $S$. intermedius. In Turkey, the investigation finding related to MR $S$. intermedius was not determined. It was considered that our different result may be associated with certain identification of $S$. intermedius, while CPS isolates are usually classified as $S$. aureus in several reports [31]. The mecA positivity found in our study was lower than the prevalence of $m e c A$ gene reported by other authors. The difference between the sample size, geographical variations and diversity in strains may be the causes of this discrepancy. It was also considered the specific and controlled antibiotic usage for the treatment of mastitis in sampling area may be effective on this result. When we conferred with veterinarians working in sampling area, they emphasized that the suitable, controlled and synergical effective antibiotics are usually used according to antibiotic susceptibility test results in Ödemiş.

One of the several virulence factors that are produced by $S$. aureus is PVL and may contribute to its pathogenicity. Generally, PVL toxin causing pneumonia and necrotizing dermatitis are more widely in human population $[17,18]$. The $p v l$ gene encoding this toxin has been reported in $0-56 \%$ of $S$. aureus strains isolated from animals with mastitis [15,33,34,38]. Zecconi et al. [38] determined the $p v l$ gene positivity as $56 \%$ in $S$. aureus strains. In another study, the $p v l$ gene was found in none of $76 \mathrm{~S}$. aureus strains isolated bovine mastitic milk samples [15]. In Turkey, Ünal [34] reported the prevalence of $p v l$ toxin gene to be $6.6 \%$ in $S$. aureus isolates, while this gene was determined in none of 16 MRSA strains by Türkyılmaz et al. [33]. We investigated $p v l$ toxin gene in 182 Staphylococcus strains by PCR and found this gene in none of strains. According to this finding, it was considered that $p v l$ gene may have not an efficient role in the pathogenesis of mastitis in terms of sampled animals and sampling area.

Methicillin resistant Staphylococci species have been recognized to be resistant to antimicrobials both all $\beta$-lactams and other than $\beta$-lactams are widely used in both human and veterinary medicine. Various researchers have emphasized that this problem causes an increase in the risk of treatment failure and cost for antimicrobial therapy and hospitalization, while the range of therapeutic options decrease [20,25]. In several studies related to the antibiotic resistance in MRSA strains isolated from animals with mastitis, the multiple antibiotic resistance have usually emphasized in strains $[16,33,35]$. We investigated the antibiotic resistance of $4 \mathrm{MR}$ S. intermedius strains against various antibiotics commonly used in Turkey. All of MR S. intermedius strains were resistant to oxacillin and cefoxitin, while 
they were sensitive to amoxicillin+clavulanic acid and cephalothin. Also, the resistance to erythromycin (50\%), rifampicin $(25 \%)$, gentamicin $(25 \%)$, tetracycline $(25 \%)$ and trimethoprim/sulfamethoxazole (25\%) was found in the mecA positive $S$. intermedius strains. Similarly other author's reports, of methicillin resistant strains, 2, 1 and 1 were resistant to 3, 6 and 5 antibiotics, respectively. We considered that geographical differences, number of tested isolates and diversity in MR strains may be effective on the antibiotic resistance levels.

\section{CONCLUSION}

In the present study, the presence of mecA gene in $S$. intermedius strains isolated from bovine quarter milk samples was reported for the first time in Turkey. It was shown that $S$. intermedius may have an efficient role in the etiology of bovine mastitis, as well as $S$. aureus. This result showed the importance of certain bacterial identification in the mastitis di- agnostic. In our study, the mecA positivity was lower than the prevalence of mecA gene reported by other authors. Nevertheless, there is a need for awareness, appropriate intervention and control measures because of the zoonosis or humanosis importance of methicillin resistant strains. Also, specific and synergical effective antibiotics should be used for the treatment of mastitis to prevent an increasing resistance problem to antimicrobials all over the world.

\section{MANUFACTURERS}

${ }^{1}$ Oxoid Microbiology Products. Hampshire, UK.

${ }^{2}$ Becton, Dickinson and Company. Franklin Lakes, NJ, USA.

${ }^{3}$ Fermentas AB. Vilnius, Litvania.

Funding. This study was financially supported by the Afyon Kocatepe University Scientific Research Projects Coordination Unit (Grand number 14.SAG.BIL.03).

Declaration of Interest. The authors report no conflicts of interest. The authors alone are responsible for the content of the paper.

\section{REFERENCES}

1 Alkan H., Baştan A., Salar S., Özdal M. \& Kaymaz M. 2014. Kuru döneme çıkarken enfekte ve sağlıklı meme loblarında California Mastitis Test ve somatik hücre sayısı ile bakteriyolojik muayene sonuçlarının karşılaştırılması. Ankara Üniversitesi Veteriner Fakültesi Dergisi. 61(3): 179-183.

2 Bhutto A.L., Murray R.D. \& Woldehiwet Z. 2012. California mastitis test scores as indicators of subclinical intramammary infections at the end of lactation in dairy cows. Research in Veterinary Science. 92(1): 13-17.

3 Cheng D.R., Zhu S.Y., Yin Z.H., Ding W.W., Mu Z.X., Su Z.R. \& Sun H.C. 2010. Prevalence of bacterial infection responsible for bovine mastitis. African Journal of Microbiology Research. 4(11): 1110-1116.

4 Choi S.M., Kim S.H., Kim H.J., Lee D.G., Choi J.H., Yoo J.H., Kang J.H., Shin W.S. \& Kang M.W. 2003. Multiplex PCR for detection of genes encoding aminoglycoside modifying enzymes and methicillin resistance among Staphylococcus species. Journal of Korean Medical Science. 18(5): 631-636.

5 Ciftci A., Findik A., Onuk E.E. \& Savasan S. 2009. Detection of methicillin resistance and slime factor production of Staphylococcus aureus in bovine mastitis. Brazilian Journal of Microbiology. 40(2): 254-261.

6 Clinical and Laboratory Standards Institute (CLSI). 2013. Performance standards for antimicrobial susceptibility testing; twenty-third informational supplement. CLSI document M100-S23. Wayne, PA.

7 Erdem Z. \& Türkyılmaz S. 2013. Molecular typing of methicillin resistant Staphylococcus aureus strains isolated from cows and farm workers. Kafkas Üniversitesi Veteriner Fakültesi Dergisi. 19(6): 963-968.

8 Fessler A.T., Billerbeck C., Kadlec K. \& Schwarz S. 2010. Identification and characterization of methicillin-resistant coagulase-negative Staphylococci from bovine mastitis. Journal of Antimicrobial Chemotherapy. 65(8): 1576-1582.

9 Frey Y., Rodriguez J.P., Thomann A., Schwendener S. \& Perreten V. 2013. Genetic characterization of antimicrobial resistance in coagulase-negative Staphylococci from bovine mastitis milk. Journal of Dairy Science. 96(4): 2247-2257.

10 Halasa T., Huijps K., Østrerås O. \& Hogeveen H. 2007. Economic effects of bovine mastitis and mastitis management: A review. Veterinary Quarterly. 29(1): 18-31.

11 Hiramatsu K., Cui L., Kuroda M. \& Ito T. 2001. The emergence and evolution of methicillin-resistant Staphylococcus aureus. Trends in Microbiology. 9(10): 486-493.

12 Hogeveen H., Huijps K. \& Lam T.J.G.M. 2011. Economic aspects of mastitis. New Zealand Veterinary Journal. 59(1): 16-23. 
C. Gezgen \& E. Seker. 2016. Investigation of Methicillin Resistance and Panton-Valentine Leukocidin in Staphylococci

13 Holt J.G., Krieg N.R., Sneath P.H.A., Staley J.T. \& Williams S.T. 1994. Bergey's Manual of Determinative Bacteriology. Philadelphia: Lippincott Williams \& Wilkins, 787p.

14 Hosseinzadeh S. \& Saei H.D. 2014. Staphylococcal species associated with bovine mastitis in the North West of Iran: Emerging of coagulase negative-staphylococci. International Journal of Veterinary Science and Medicine. 2(1): 27-34.

15 Ikawaty R., Brouwer E.C., Wan Duirskeren E., Mevius D. \& Verhoef J. 2010. Virulence factors of genotyped bovine mastitis Staphylococcus aureus isolates in the Netherlands. International Journal of Dairy Science. 5(2): 60-70.

16 Kreausukon K., Fetsch A., Kraushaar B., Alt K., Muller K., Kromber V., Zessin K.H., Käsbohrer A. \& Tehhagen B.A. 2012. Prevalence, antimicrobial resistance, and molecular characterization of methicillin-resistant Staphylococcus aureus from bulk tank milk of dairy herds. Journal of Dairy Science. 95(8): 4382-4388.

17 Lina G., Piemont Y., Godail-Gamot F., Bes M., Peter M., Gauduchon V., Vandenesch F. \& Etienne J. 1999. Involvement of Panton-Valentine leukocidin-producing Staphylococcus aureus in primary skin infections and pneumonia. Clinical Infectious Diseases. 29(5): 1128-1132.

18 Lo W. \& Wang C. 2011. Panton-Valentine leukocidin in the pathogenesis of community-associated methicillin-resistant Staphylococcus aureus infection. Pediatrics and Neonatology. 52(2): 59-65.

19 Luini M., Cremonesi P., Magro G., Bianchini V., Minozzi G., Castiglioni B. \& Piccinini R. 2015. Methicillinresistant Staphylococcus aureus (MRSA) is associated with low within-herd prevalence of intra-mammary infections in dairy cows: Genotyping of isolates. Veterinary Microbiology. 178(3-4): 270-274.

20 Lowy F.D. 2003. Antimicrobial resistance: The example of Staphylococcus aureus. Journal of Clinical Investigation. 111(9): 1265-1273.

21 Middleton J.R. 2013. Staphylococcus mastitis: Have we learned anything in the last 50 years? In: NMC 52nd Regional Meeting Proceedings (San Diego, USA). pp.1-8.

22 Moon J.S., Lee A.R., Kang H.M., Lee E.S., Kim M.N., Paik Y.H., Park Y.H., Joo Y.S. \& Koo H.C. 2007. Phenotypic and genetic antibiogram of methicillin-resistant Staphylococci isolated from bovine mastitis in Korea. Journal of Dairy Science. 90(3): 1176-1185.

23 National Mastitis Council. 1999. Laboratory handbook on bovine mastitis. Revised edn. Madison: National Mastitis Council Inc., 30p.

24 Pehlivanoğlu F. \& Yardımcı H. 2012. Detection of methicillin and vancomycin resistance in Staphylococcus strains isolated from bovine milk samples with mastitis. Kafkas Üniversitesi Veteriner Fakültesi Dergisi. 18(5): 849-855.

25 Pinho M.G., Filipe S.R., de Lencastre H. \& Tomasz A. 2001. Complementation of the essential peptidoglycan transpeptidase function of penicillin-binding protein 2 (PBP2) by the drug resistance protein PBP2A in Staphylococcus aureus. Journal of Bacteriology. 183(22): 6525-6531.

26 Pyörälä S. 2003. Indicators of inflammation in the diagnosis of mastitis. Veterinary Research. 34(5): 565-578.

27 Sargeant J.M., Leslie K.E., Shirley J.E., Pulkrabek B.J. \& Lim G.H. 2001. Sensitivity and specificity of somatic cell count and California mastitis test for identifying intramammary infection in early lactation. Journal of Dairy Science. 84(9): 2018-2024.

28 Schalm O.W., Carroll E.J. \& Jain N.C. 1971. Bovine mastitis. Philadelphia: Lea \& Febiger, 360p.

29 Spohr M., Rau J., Friedrich A., Klittich G., Fetsch A., Guerra B., Hammerl J.A. \& Tenhagen B.A. 2011. Methicillin-resistant Staphylococcus aureus (MRSA) in three dairy herds in Southwest Germany. Zoonoses and Public Health. 58(4): 252-261.

30 Strommenger B., Kettlitz C., Werner G. \& Witte W. 2003. Multiplex PCR assay for simultaneous detection of nine clinically relevant antibiotic resistance genes in S. aureus. Journal of Clinical Microbiology. 41(9): 4089-4094.

31 Taponen S. 2008. Bovine mastitis caused by coagulase-negative Staphylococci. 64p. Thesis (Academic Dissertation). Faculty of Veterinary Medicine, University of Helsinki, Finland.

32 Tenhagen B.A., Koster G., Wallmann J. \& Heuwieser W. 2006. Prevalence of mastitis pathogens and their resistance against antimicrobial agents in dairy cows in Brandenburg, Germany. Journal of Dairy Science. 89(7): 2542-2551.

33 Türkyılmaz S., Tekbıyık S., Oryasin E. \& Bozdogan B. 2010. Molecular epidemiology and antimicrobial resistance mechanisms of methicillin resistant Staphylococcus aureus isolated from bovine milk. Zoonoses Public Health. 57(3): 197-203.

34 Ünal N. 2013. Subklinik mastitisli inek sütlerinden izole edilen Staphylococcus aureus izolatlarında bazı toksin genleri ve metisilin direnç geninin ara tırılması. Ankara Üniversitesi Veteriner Fakültesi Dergisi. 60(1): 21-26. 
C. Gezgen \& E. Seker. 2016. Investigation of Methicillin Resistance and Panton-Valentine Leukocidin in Staphylococci Isolated from Bovine Mastitis. Acta Scientiae Veterinariae. 44: 1373.

35 Vanderhaeghen W., Cerpentier T., Adriaensen C., Vicca J., Hermans K. \& Butaye P. 2010. Methicillin-resistant Staphylococcus aureus (MRSA) ST398 associated with clinical and subclinical mastitis in Belgian cows. Veterinary Microbiology. 144(1-2): 166-171.

36 Vishnupriya S., Antony P.X., Mukhopadhyay H.K., Pillai R.M., Thanislass J., Vivek Srinivas V.M. \& Sumanth Kumar R. 2014. Methicillin resistant staphylococci associated with bovine mastitis and their zoonotic importance. Veterinary World. 7(12): 422-427.

37 Waller K.P., Aspan A., Nyman A., Persson Y. \& Andersson U.G. 2011. CNS species and antimicrobial resistance in clinical and subclinical bovine mastitis. Veterinary Microbiology. 152(1-2): 112-116.

38 Zecconi A., Cesaris L., Liandris E., Daprá V. \& Piccinini R. 2006. Role of several Staphylococcus aureus virulence factors on the inflammatory response in bovine mammary gland. Microbial Pathogenesis. 40(4): 177-183.

39 Zhang K., Sarling J., Chow B.L., ElSayed S., Hussain Z., Church D.L., Gregson D.B., Louie T. \& Conly J.M. 2004. New quadriplex PCR assay for detection of methicillin resistance and simultaneous discrimination of $S$. aureus from coagulase-negative Staphylococci. Journal of Clinical Microbiology. 42(11): 4947-4955. 